\title{
TWO LIBRARIANS, AN ARCHIVIST, AND 13,000 IMAGES: COLLABORATING TO BUILD A DIGITAL COLLECTION
}

\author{
Nancy Chaffin Hunter, ${ }^{1}$ Kathleen Legg, ${ }^{2}$ and Beth Oehlerts ${ }^{3}$
}

Colorado State University Libraries has been creating digitized collections, primarily from its Archives and Special Collections unit, since 2000. These projects involved collaboration among Archives, Cataloging, and Digitization; the most recent and ambitious project, digitizing 13,000 historical images of the university dating from the 1880 s into the 1930 s, required closer collaboration than any previous project. The three authors, each with a distinctive role in the project, use this case study to illustrate and discuss in detail the different professional and technical skills and perspectives that each brought to the project and how they learned from each other. The authors present lessons learned in how to effectively build successful internal partnerships to further digitization projects.

\section{Introduction}

The University Historic Photograph Collection (UHPC) [1] documents over one hundred years of the history of Colorado State University (CSU) and the surrounding community of Fort Collins, Colorado. It is a rich resource that preserves institutional memory, raises awareness of visual literacy, and serves the current campus community's need to access images for scholarly research, special events, and marketing. The collection became part of the CSU Libraries (CSUL) Archives and Special Collections department in 2006 through an interdepartmental transfer from the Communications and Creative Services (CCS) department, home to the campus

1. Metadata Librarian, Colorado State University Libraries, Colorado State University, Campus Delivery 1019, Fort Collins, CO 80523-1019; E-mail Nancy.Hunter@ColoState.edu.

2. Archivist and Digital Collections Librarian, NCAR Library, P.O. Box 3000, Boulder, CO 80307-3000. (Formerly Project Archivist, Colorado State University Libraries, Colorado State University, Fort Collins, CO); E-mail klegg@ucar.edu.

3. Metadata Management Librarian, Colorado State University Libraries, Colorado State University, Campus Delivery 1019, Fort Collins, CO 80523-1019; E-mail Beth.Oehlerts@ ColoState.edu.

[Library Quarterly, vol. 80, no. 1, pp. 81-103]

(C) 2010 by The University of Chicago. All rights reserved. 0024-2519/2010/8001-0004\$10.00 
photographers. The UHPC consists of all photography commissioned by the university from the 1880 s to the present. Faculty members, football games, scholarly research, and historic downtown Fort Collins are among the subjects depicted in the collection.

The half of a million images, predominantly negative-based, represent a time line of photographic history, from glass plate negatives and cabinet cards to 35-millimeter color film and digital image files. In 2007, CSUL planned to digitize the oldest materials and deliver them via the Web. The oldest materials were selected based on age, preservation concerns, and historical significance. The materials most at risk for image loss, the glass plate negatives, magic lantern slides, and silver gelatin prints from nitrate film, were given the highest priority for digitization. The glass plate negative and magic lantern slide subcollection consists of over 5,000 items dating from the 1880 s to the 1930 s, the earliest history of the university. A second subcollection contains 7,500 silver gelatin prints, dating from the 1920s to the 1940s, glued to acidic $8 \times 10$-inch index cards. These prints came from cellulose nitrate film, which CCS destroyed in 1980 due to hazardous levels of deterioration. More UHPC materials will be digitized in the future as resources permit and patron needs arise.

The project goal of making the collection available to a large user base through the means of digitization and online delivery required a collaborative effort among CSUL archivists and librarians. In particular, a project archivist, a digital projects librarian, and a metadata librarian relied on one another's professional strengths to create the UHPC Digital Collection collaboratively. The archival mission is "to identify records and papers of enduring value to preserve them and make them available to patrons" [2, p. 3]. The CSUL's goal for the UHPC digitization project was to use archival arrangement and description, image capture, and metadata to streamline discovery of, and access to, this vast photograph collection while preserving the materials. Through this effort, the UHPC and its many stories yet to be discovered will be available to a wider audience.

The desire to make unique images available was the key factor driving digitization. These images link the history of CSU and its students and faculty to local, state, and national issues, recording, for example, the university's contributions to society. A handful of photographs from the World War II era found in file cabinet drawers labeled "Students: Groups" depict CSU students harvesting sugar beets from local farmers' fields, collecting scrap metal, and participating in an event dubbed "Yarn for Britain." Photographs that document the work of a CSU faculty member in founding the Peace Corps are tucked away in the "Groups and Individuals" file. Digitization and online delivery of components of the UHPC provides access to these connections.

As a whole, the UHPC lacks uniform access points, which hinders patron 
use and increases preservation risks. While in the care of CCS, these images functioned as a stock-photograph collection. Staff from campus departments or outside users needing images for university functions or other research could search through a dozen file cabinets of prints roughly organized by subject. A patron researching early agricultural organizations in Fort Collins, such as the Grange, could not search specifically for Grangerelated images but, instead, physically browsed hundreds of photographs grouped together under the heading "Rural People and Things." While a majority of the prints housed in the file cabinets had corresponding negatives stored elsewhere, there were several thousand prints with no matching negatives; they are the only copies. A combination of the finding aid and online delivery will mitigate some risks by decreasing physical handling.

Convergence: Archivists and Librarians

Differences in professional methodologies between archives and libraries include the nature of materials collected, approaches to description and discovery, and definitions of access. Initially these differences impaired communication and effective collaboration. For example, archivists describe collections at the aggregate level, focusing on provenance and original order. Librarians describe individual publications, focusing on the intellectual content and the description of the resource itself. Archivists rely on the finding aid, a document guided by the organic structure of the collection, as the discovery tool. Librarians rely on structured records (MARC, Dublin Core, etc.) and bibliographic systems as the discovery tool.

The project archivist and the librarians shared goals but, as illustrated above, naturally sought different objectives for the project related to their professional disciplines. The objective of the Coordinator of Archives and Special Collections and the project archivist was to make this historic collection available using archival principles. The digital projects librarian's objective was to create the best digital images possible according to appropriate standards in her role as manager of the digital image team. The metadata librarian's objective was to provide sufficient metadata to facilitate discovery.

At the planning stage of the UHPC Digital Collection, project participants did not fully recognize how crucial collaboration would be to success. The CSUL's digitization work often includes participants from many departments, but the UHPC Digital Collection was the largest project to date. The work flow designed for the UHPC digitization project illustrates this level of collaboration (see fig. 1). Although not consciously aware of professional cultural differences, the participants spent time translating archival, digitization, and metadata vocabularies and philosophies to one 


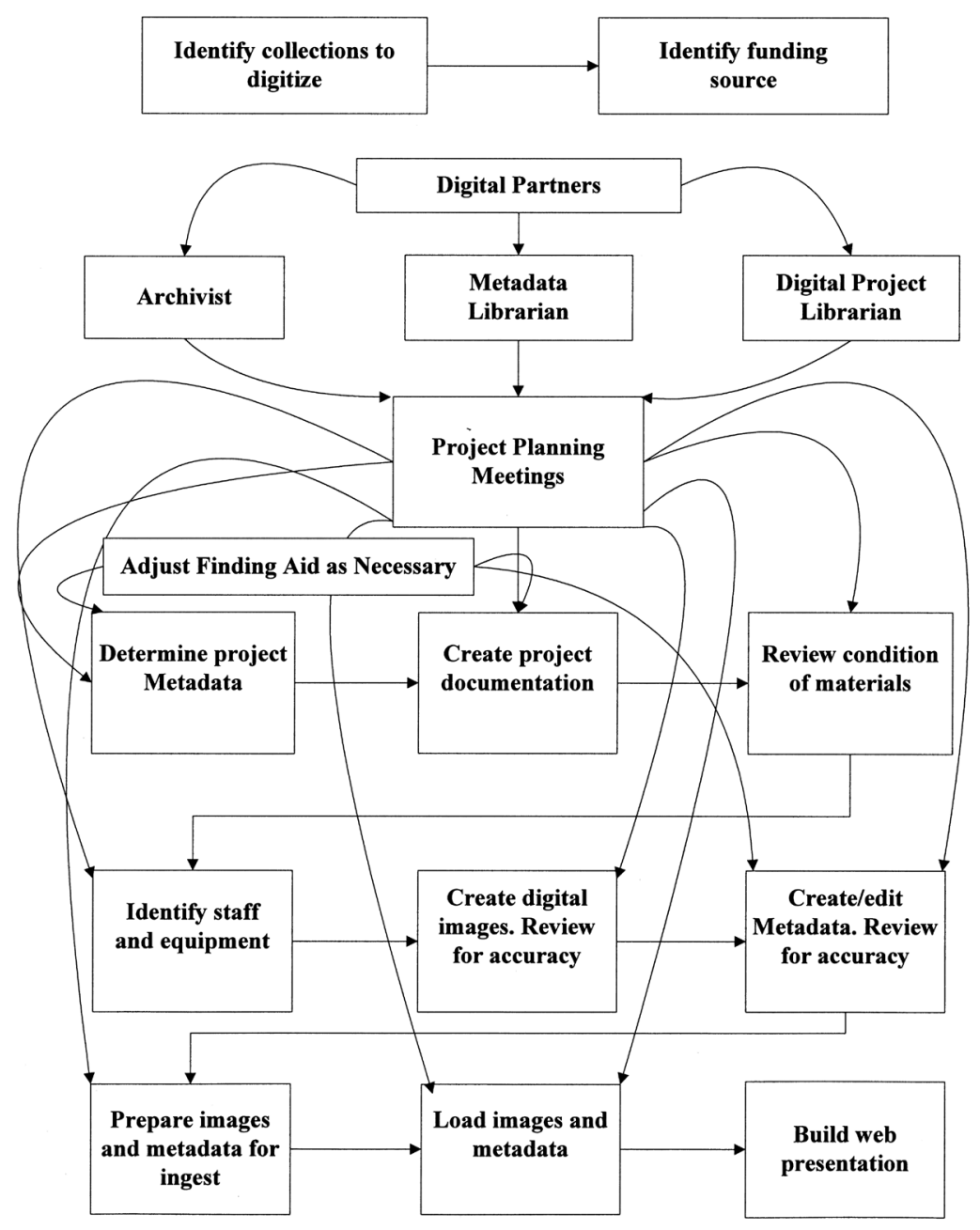

Fig. 1.-Work flow for digitization projects

another. The project archivist and the librarians learned the value of communication and interdependency in building the UHPC Digital Collection.

Literature Review

The digital environment increasingly drives collaboration between archivists and librarians. Many institutions consider archival and special collec- 
tions materials to be perfect digitization projects as these unique items can differentiate a library or archive from its peers as well as improve access while ensuring preservation of the originals. ${ }^{4}$ Digitization projects require a partnership among information professionals during most phases of the project, from materials selection to metadata creation to building a userfriendly searchable online interface. However, these allied information professionals have experienced obstacles to collaboration. The professional literature has explored the relationship between archivists and librarians for decades, and the drive to digitize holdings continues this conversation and offers new ways to build bridges between professions, as demonstrated by the UHPC digitization project at CSUL.

A large body of literature is devoted to defining archives and the archival profession as archivists historically struggled to differentiate their work from the fields of history and library science. In the United States, the recognition of archives as a distinct profession did not occur until the first decades of the twentieth century, and many more years would pass before archivists formally defined archival methodology and what it meant to be an archivist [8]. In 1944, ten years after the opening of the National Archives, Herman Kahn addressed the Society of American Archivists, choosing the topic of professional methodologies of the librarian and the archivist [9]. Kahn illustrated through various examples the differences between archival methodology and library science, insisting that archival materials be managed and organized according to provenance and original order to maintain "the integrity of the records themselves" as opposed to subject-based organization schemes [9, p. 251]. Kahn defended the thenfledgling archival profession against criticisms leveled at the usefulness of archival arrangement and description to researchers accustomed to library methods of subject classification, arguing that an archivist could never "anticipate what subjects persons are going to be interested in and arrange them in such a manner to please all such persons" [9, p. 250]. Provenancebased order was the logical solution.

Kahn would not be the last to offer an opinion about the relationship between archival and library methodologies or to defend the archival profession from the perspective of what it is not: history or library science. For the UHPC, the project archivist followed archival methodology and created a finding aid with differing levels of description moving from general to specific to meet the needs of a variety of users, while consistently pointing to the original context and purpose of the images. The need for archival arrangement and the creation of subseries is illustrated by the original organization scheme of over 800 glass plates in several cabinet

4. In addition to the works cited in the article, many authors discuss the rationale behind digitizing materials from archives and special collections departments. See [3-7]. 
drawers depicting cattle, all classified under "Animal Husbandry." These pictures stemmed from various projects and uses-from college herds raised by students as part of a degree program and 4-H Club heifer projects to faculty-led research trials investigating the effects of feed types on beef production. If left as found, the cows lose context, the "why" a photographer traveled across campus to the College Farm to take a picture of cattle milling about the pasture. Returning to the original purpose for creating the image drove archival arrangement and description, helping to "bring the cows home" by dividing them among the appropriate subseries, such as Academics, Extension, and Experiment Station. These divisions bring to light the relevance of agricultural training and research to university history and its responsibility as a land-grant college to disseminate the newest scientific methods.

Thirty-two years later, a compilation of nineteen essays was published in Archive-Library Relations [10]. According to the editor, the focus of the volume was to create an understanding between the archival and library professions, to "contribut[e] to the archivist's knowledge of libraries" and "the librarian's understanding of the potential of original source materials" $[10$, p. xii]. The articles discuss the methodology of each group, similarities, differences, common issues, shared concerns, and professional communication. The work argues that this side-by-side comparison of the professions and outline of joint issues and concerns will spark a foundation of understanding that will serve as the means to exploring overlapping spheres where convergence may be possible in the future. The UHPC digitization project illustrates those overlapping spheres and lays the foundation for how those concerns can be resolved.

William Birdsall continues the discussion of archives-library relations in 1979 in "Archivists, Librarians, and Issues during the Pioneering Era of the American Archival Movement" [11]. Going deeper into the subject than Archives-Library Relations, Birdsall follows Kahn by defining archives and archivists by what they are not: libraries and librarians. He traces the history of archives, focusing on formulation of archival methodology and the professional identity of archivists. Prior to the establishment of a distinct archival profession, librarians typically arranged and described archival collections using library methodology. Consequently, archivists struggled to distinguish archival materials as something different enough from library collections to require different strategies of organization and management. During the dawn of the archival profession, archivists often defined themselves and their materials in oppositional language, using the established field of library science to contrast the newly emerging archival field. Birdsall reminds his readers that this early history of archives "must be understood in any consideration of archives-libraries relations" [11, p. 475]. As the history of the profession shows, relationships between the groups may be 
hindered. Collaboration between archivists and librarians involves compromise and negotiation. After decades of forging a distinct professional identity and methodology, collaboration and its resulting compromises and negotiations have resulted in an evolving relationship between professions. Similarly, Gerry Bernbom, Joan Lippincott, and Fynette Eaton's article "Working Together: New Collaborations among Information Professionals" states that one of the barriers to a successful collaboration can be the differing lexicons of archivists and librarians [12]. When the archivists and the librarians began working collaboratively on the UHPC digitization project, they discovered these differences in their respective professional lexicons. For example, the simple term "access" carried differing connotations across the library-archive divide. The librarians considered access to mean delivery to the end user, whereas the archivists added concerns around copyright and confidentiality to the term "access."

Another collection of essays, published in 1986 under the title Archives and Library Administration: Divergent Traditions and Common Concerns [13], again brings together several authors concentrating on the topic of archivists and librarians but with a decidedly different tone than ArchivesLibrary Relations. Editor Lawrence J. McCrank states that the goal of the book was "to create a much needed dialogue across professional lines about the commonalities and differences . . . and how these points of splintering and convergence affect managerial and administrative decision making" [13, p. 8]. McCrank and many of the essayists argue that although both groups have discussed similarities and differences and the need for collaboration, little progress has been made toward that goal, mainly because organizationally archives are often subjugated to libraries. The dominance of library concerns and methods has afffected how archives do business. Despite feelings of "defensive posture, distrust, and misunderstanding" [13, p. 9], there are "a number of areas where there is a real convergence of values and ideas . . . where differences continue and require not agreement, but a realistic appreciation of and respect for the differences" [13, p. 18]. A few essayists identify technology in particular as a point of collaboration by considering the ways in which technology is affecting both the archival and library worlds and ultimately blurring distinctions between the two. Participating in the UHPC digitization project has facilitated a respect for the differences between professions, as both archival and library science methodologies were required to successfully complete the project.

In 1990, William J. Maher began to hash out solutions to professional barriers between archivists and librarians by examining the relationships between academic archivists and librarians in "Improving Archives-Library Relations: User-Centered Solutions to a Sibling Rivalry" [14]. Maher describes barriers to cooperation between academic archivists and librarians but also offers strategies for improved relations. He begins his discussion 
by looking at the history of academic archives and libraries and considering commonalities such as shared goals and users, which creates an atmosphere ripe for collaboration. However, differences in professional approaches limit collaboration and create tension in the four areas of mission, resources, methodology, and professional backgrounds. Archivists collect unique, unpublished materials that often enter the archives by way of donation. Librarians collect publications that are often purchased. Archivists arrange and describe at the aggregate level while librarians arrange and describe at the item level. Archivists enter the profession from more than one educational path whereas librarians typically must hold a Master of Library Science degree. In Maher's opinion, variations in these four areas create strain between professions and erect barriers to effective collaboration.

The solution to improving relations and creating a solid foundation for collaborative work lies in Maher's argument that "archivists and librarians should be encouraged to view themselves as their users see them-merely as different facets of the totality of information resources" [14, p. 358]. He offers several strategies for increased cooperation between archivists and librarians that focus joint efforts on serving users rather than "a dogmatic emphasis on methodological differences" [14, p. 362]. Both sides must bear in mind that they share a common goal: to help people find and access information. Maher points out that to improve archives-library relations, "realistic mechanisms for increased coordination in the daily work of archives and libraries, where most conflicts and tensions arise" are needed [14, p. 355].

In "Architectures for Collaboration: Roles and Expectations for Digital Libraries" [15], Peter Brantley points out that the preservation of library collections is an act of forging memories. He observes that collaboration is essentially "building bridges" with your communities, which rings true to those who have experienced it firsthand [15, p. 38]. These experiences taught that working collaboratively expands the concept of the library user. In the UHPC digitization project, the project archivist and the librarians not only understood their work as different aspects of the same goal of serving their users but also developed "realistic mechanisms" such as direct lines of communication and a working group to build a successful partnership.

Joanne Kaczmarek continues the theme of both Maher's and Brantley's articles, focusing on user-centered strategies to drive collaboration between archivists and librarians, but she applies it specifically to the current digital environment in "The Complexities of Digital Resources: Collection Boundaries and Management Responsibilities" [16]. Kaczmarek shows that the digital environment blurs boundaries between information professions, but despite the shared goal of meeting users' needs, the dissimilarity between the daily activities of archivists and librarians restricts collaboration. If both 
groups seek to achieve user-centered goals, roles in the management of digital collections must shift toward a shared approach of stewardship across professions. Kaczmarek states that "developing and supporting the necessary technical and organization infrastructure for long-term sustainability of digital collections will require intentional collaboration among information professionals" [16, p. 215]. Without intentional partnerships, archivists and librarians will not meet the needs of users searching for reliable digital information. Collaboration is not an option; it is mandatory to meet user-centered goals. Management of CSUL digital projects is just such a partnership. All current digital projects are guided by the CSUL Repositories Matrix Team, which consists of the department coordinators for Archives and Special Collections, Metadata and Preservation Services, Digital Repository Services, Library Technology Services, Collections and Contracts, and a representative from the College Liaisons. This interdepartmental management team assures that communication reaches all project participants.

Successful partnerships built through teamwork are the point of Dayna Holz's "Technology Enhanced Archival Collections: Using the Buddy System" [17]. The article focuses on a large digitization project that relied on partnering with various organizations to provide the appropriate expertise to make the project a success. Archivists are experiencing a surge in user demands for collections to be available quickly and conveniently online, an issue that Holz points out "librarians have been dealing with for years" $[17$, p. 31]. She clearly demonstrates that when it comes to large digital projects, archivists cannot do it alone; outside expertise is required in areas such as metadata and programming. The archivist in the UHPC digitization project could not have delivered the collection online without the help of the librarians, who possess expertise available outside the Archives and Special Collections department. Holz believes that by reaching out and building partnerships, digital projects are "innovative mutually beneficial collaborative venture[s]" [17, p. 41]. Digitizing the UHPC left the project archivist and the librarians in agreement that their partnership was mutually beneficial to both sides of the professional divide. The innovative and collaborative process for creating digital collections preserved both groups' project goals without compromising the fundamental tenets of our respective methodologies.

In "Collaboration as a Wave of Future: Exploring Experiences from Croatian Archives" [18], Sanjica Faletar Tanackoviæ and Boris Badurina conducted a survey to explore the relationship between archives, museums, and libraries, placing their research against the backdrop of a sizable body of literature addressing convergence among cultural heritage institutions. The authors find that although these organizations differ in methodology, they share the same goal: "preservation and communication of world heritage" [18, p. 557]. The digital environment and user expectations that 
accompany it are transcending the traditional boundaries between libraries, archives, and museums. According to Tanackoviæ and Badurina, the digital environment demands collaboration between archivists and librarians if they are to meet their goals of information preservation and access. Again, echoing Kaczmarek, collaboration is mandatory in the digital environment.

Shan Sutton delves into the archives-library relationship as it pertains to digital projects in "Navigating the Point of No Return: Organizational Implications of Digitization in Special Collections" [19]. Sutton examines a 1998 survey undertaken by the Association of Research Libraries, using the results to explain that digital projects necessitate collaboration between special collections and digital departments within the academic libraryarchivists cannot "go it alone," to reiterate Holz's arguments. Sutton argues that "supporting digitization involves organizational issues that consistently go beyond the boundaries of special collections" [19, p. 239]. This is changing how librarians and archivists work in the academic library; they "need each other to meet their intertwined goals and objectives" [19, p. 239]. Archivists are taking on new roles to become active project partners when building digital collections. They are helping librarian colleagues to maintain the archival concepts that govern the arrangement and description of archival collections, such as provenance and original order, in the online environment. In turn, digital library staff are improving archivists' ability to meet their goals of insuring that archival collections will be "fully accessible, searchable, and sustainable over time" [19, p. 241]. Collaboration between archivists and librarians guides each group to reach their goals. For example, the archivists and librarians involved in the UHPC digitization project came together early in the project to discuss metadata creation for the images, laying the groundwork for collaboration. They determined that metadata creation would begin with the project archivist, a logical starting point as she possessed firsthand knowledge of the collection. While the project archivist was developing the finding aid that would serve as the initial source of the metadata for the UHPC Digital Collection, the metadata librarian developed the UHPC Data Dictionary, based on the locally developed CSU Core Data Dictionary. ${ }^{5}$ A list of the metadata elements may be found in appendix A. Without this collaboration, neither the goal of preserving archival context nor that of providing resource discovery would be met.

Sterling Coleman Jr. focuses on archivists and librarians working together at Auburn University in "The Archival and Library Viewpoints of a Collection in a Digital Environment: Is There Any Room for Compromise?" [21]. He points out that the "emergence of digital libraries" caused aca-

5. A full discussion of the development of the CSU Core Data Dictionary can be found in [20]. 
demic libraries to actively create "digital material that they [could] readily draw from their immediate community," such as archives and special collections materials [21, p. 104]. Creating content for digital libraries has created conflict between archivists and librarians as each group defines, arranges, and describes collections in a different way. Archivists are concerned about their collections losing context in a digital environment that allows materials to be arranged and displayed "on an item level rather than on a collection or record series level" [21, p. 106]. However, Coleman points out that through communication and negotiation both groups can come together to "forge a compromise that respects both the archival principles of provenance and original order, yet provides ease of access to users of the digital library" [21, p. 108]. Compromise and negotiation characterized the relationship between the project archivist and the librarians during the UHPC digitization project. Archival principles were preserved while the user benefited from excellent access to the collection.

Many accounts of archivists and librarians collaborating on digital projects have been published in the last several years, and many mirror aspects of the UHPC digitization project. For example, in "Reference Implications of Digital Technology in a Library Photograph Collection" [22], William E. Benemann discusses issues with describing photographs in the online environment at the University of California, Berkeley's Bancroft Library. He notes concerns surrounding how to determine Library of Congress subject headings "even though we cannot ever anticipate all the reference questions that a given image may satisfy" and points out problems encountered with misspelled and illegible captions that can leave an archivist or a librarian unsure of accurate names, places, and dates [22, p. 45]. These are all issues experienced with the UHPC digitization project as well. The end product of the project is having the images available online through the CSUL Digital Repository (Repository). Each image stored in the Repository has an individual metadata record, and, accordingly, information about each item is needed. The project archivist decided to implement item-level processing of the UHPC subcollections to have detailed information about the oldest materials in the collection and to meet the needs of digitization. The juncture of digitized archival materials and the Repository is an intersection between archivists and librarians at CSUL; both archival and library science methodologies are applied to materials through close collaboration.

Collaboration

Digitization broadened the scope of collaboration to include participants across multiple CSUL departments. The success of the project relied on 
communication between several groups, providing an educational experience for all. During the creation of the UHPC Digital Collection, the project archivist, digital projects librarian, and metadata librarian collaborated to plan, answer questions, and resolve problems.

Descriptive information for archival collections, especially a large photograph collection with little textual documentation, can be challenging to translate to librarians unfamiliar with the philosophical foundations of archival description. Likewise, a librarian's preference for definitive names and dates was not familiar to an archivist accustomed to working with a lack of information about individual items, especially photographs. The project archivist and the librarians were open to learning about one another's methodologies in order to meld these approaches to fulfill mutual goals.

The first collaborative meetings focused on project requirements from different professional perspectives. The project archivist wanted to ensure appropriate care and handling during scanning, the digital projects librarian required server space and access to the collection, and the metadata librarian concentrated on image identifiers and appropriate descriptions. Following these start-up meetings, communication was primarily through e-mail, as the project archivist's office and the photograph collection were in a separate building, the Archives Annex, several blocks from the library. Equipment problems also brought the project participants together to explore options to stay on schedule. For example, project participants struggled with the difficulties of obtaining high-quality images from modern scanning equipment not designed for obsolete formats.

Collaboration continued between the project archivist, the digital projects librarian, and the digital image team during the scanning stage. After processing the two subcollections slated for digitization, the project archivist identified potential problems in the scanning stage due to format as well as problems with the numbering. Prior to scanning, the project archivist briefed the digital projects librarian on the types of materials that might require adjustments to the scanning procedure. The digital image team communicated frequently with the project archivist whenever concerns arose about the arrangement or description of the collection.

Due to differing work locations, there was some confusion over responsibilities for reporting equipment failures and other minor project issues. To alleviate this confusion, the Repositories Matrix Team created the Digital Projects Management Plan Working Group (Working Group) in early 2008 to provide a formal communication structure to aid collaborative efforts. The Working Group includes representatives from all CSUL departments involved in digitization projects. The first priority for the Working Group was to monitor the progress of the UHPC digitization project. The Working Group maintains a wiki that holds digital project documen- 
tation; links to international, national, and local best practices documentation; CSUL digitization policies; metadata guidelines; internal scanning forms and procedures; and planning documents. The wiki is accessible to all staff over the CSUL intranet. Staff who are responsible for digital projects record their progress on documents on the wiki and use the wiki to verify the status of any current planned digitization project. The Working Group and the wiki have improved communication and will continue to streamline communications for future digitization projects.

The idiosyncrasies of the UHPC required close collaboration between the project archivist and the metadata librarian in particular. The metadata librarian did not work where the physical collection is housed; she only had access to the digital version of the images. The original structure of the UHPC and inconsistencies in numbering, captions, and dates created a complex collection; it took the project archivist several months to fully gain intellectual and physical control. To create the most effective metadata for the collection, the metadata librarian had to step into the project archivist's shoes. The project archivist invited the metadata librarian for a tour of the Annex, imparting an appreciation of the idiosyncratic collection from an archivist's perspective through an extended conversation. For example, the original enclosure titles, which the project archivist transcribed to the finding aid, included abbreviations such as "A.H." (Animal Husbandry). While clear to the project archivist, these initials confounded the metadata librarian until she gained an understanding of the intellectual structure of the finding aid and the breadth of the collection. The project archivist and metadata librarian collaborated throughout the rest of the project on issues such as this, continuing to resolve problems with the metadata and the finding aid.

This was the first time that the metadata librarian worked with an archivist during the creation of a finding aid. Over the course of several conversations with the project archivist, the metadata librarian had a more complete understanding of the intellectual work necessary to process a collection of this size and at this level of detail. Understanding the physical collection had never been necessary when creating metadata for smaller, homogeneous, focused collections; generally, the metadata librarian dealt almost exclusively with the digital objects, not the original artifacts and their organization. One example of the metadata librarian's need to understand the physical collection occurred with inconsistencies in the creator-assigned numbers to images of individual football players. At times, the creator assigned one number for three players captured on one glass plate while at other times a number for each of the three players was assigned even though they were all on a single plate. These inconsistencies required close collaboration with the project archivist to understand the collection and build appropriate metadata. 
In a similar vein, the metadata librarian became more involved than usual in the scanning process. Discussions with the digital projects librarian led to repurposing the digitization documentation to create the spreadsheet used to record complete metadata. This spreadsheet came to the metadata librarian already populated with number, title, image orientation, size of the original, and any condition assessment note. Being able to build upon this existing data streamlined the creation of the remaining metadata and actually provided information difficult or impossible to determine from the digital image only.

Quality control reviews of scanned images were done regularly, but not usually at 100 percent. Because metadata staff viewed every image to provide the description, they were able to identify the occasional file-naming error, incorrect orientation of an image, and even some scanning errors. The metadata librarian was the liaison to the digital image team, the digital projects librarian, and the project archivist when such errors were identified and worked with all three to resolve the problem. Images requiring rescanning were relayed to the digital image team, and the corrections were made prior to creating the access images and loading into the Repository.

\section{Lessons Learned}

\section{Project Archivist}

Through working with the librarians on the UHPC digitization project, the project archivist gained the perspective of her librarian colleagues approaching an unfamiliar archival collection and their needs in the digitization project. The project archivist modified her processing work flow, while still working in accordance with archival methodology, to account for the requirements of digitization. She designed her condition assessment spreadsheet with the needs of the digital image team in mind by organizing materials according to physical location rather than the intellectual organization of the finding aid. This aided in locating entries, which saved time. In collaboration with the metadata librarian, the project archivist worked to create standards for handling how inconsistencies in the collection were recorded in the finding aid and ultimately in the metadata. The item-level inventory of the finding aid is over 400 pages long; collaboration between the project archivist and metadata librarian on the finding aid led to a polished document ready for publication. Arrangement at the item level provided the opportunity to improve preservation of the materials for future use. The glass plates and gelatin prints each represent a series in the finding aid, with further granularity at a subseries level. Additional division occurs within each subseries when necessary for ease of discovery and access. For example, the subseries Academics is divided by 
College, such as College of Agriculture, College of Engineering, and College of Home Economics. Subseries and further divisions aided the metadata librarian in assigning subject headings at an aggregate level to the digital objects.

The finding aid for the UHPC formed the basis of the metadata input by staff as directed by the metadata librarian. As such, the finding aid was examined in detail to extract metadata elements at the item level. This scrutiny revealed both small inconsistencies and transcription errors that needed to be resolved prior to creating the metadata. The project archivist learned that it was necessary to work closely with the metadata librarian to respond to the need for accurate metadata. For example, captions on some enclosures included misspelled words. To enable resource discovery with a title search, the project archivist had to verify that the misspelling was done by the creator of the collection; then the metadata librarian could supply an additional title with the correct spelling (see fig. 2).

\section{Digital Projects Librarian}

Documenting the creation of the UHPC Digital Collection provided the project archivist, the digital projects librarian, and the metadata librarian with the information needed to identify project efficiencies and necessary changes. During the planning stage, the digital projects librarian began designing and identifying project documentation to track progress and assist the digital image team in digitizing materials in the correct sequence. The goal was to create a document that would allow recording the work of each person creating digital images and the results of the quality control review. The information collected gave the digital imaging supervisor the ability to monitor and evaluate the performance of staff, correct image problems, and identify any images not scanned. The digital projects librarian adapted the condition assessment spreadsheet created by the project archivist during her preliminary inventory. This spreadsheet eventually contained all the project data, from the start of the project to the inclusion of the descriptive metadata for each image, thereby functioning as project tracking software.

Communication through the life of the project helped to resolve problems quickly and helped to create this valuable digital collection. Discussions with project participants took place through a variety of channels: in meetings, via e-mail, or by telephone. Meeting minutes or notes taken during each conversation were posted on the staff wiki for future reference. The project archivist, under the supervision of the Coordinator of Archives and Special Collections, was the daily contact for the digital image team. She answered questions about the condition of the materials and assisted with identification of items prior to scanning. Creating the images at the Annex proved to be a benefit for the digital image team, as the project 


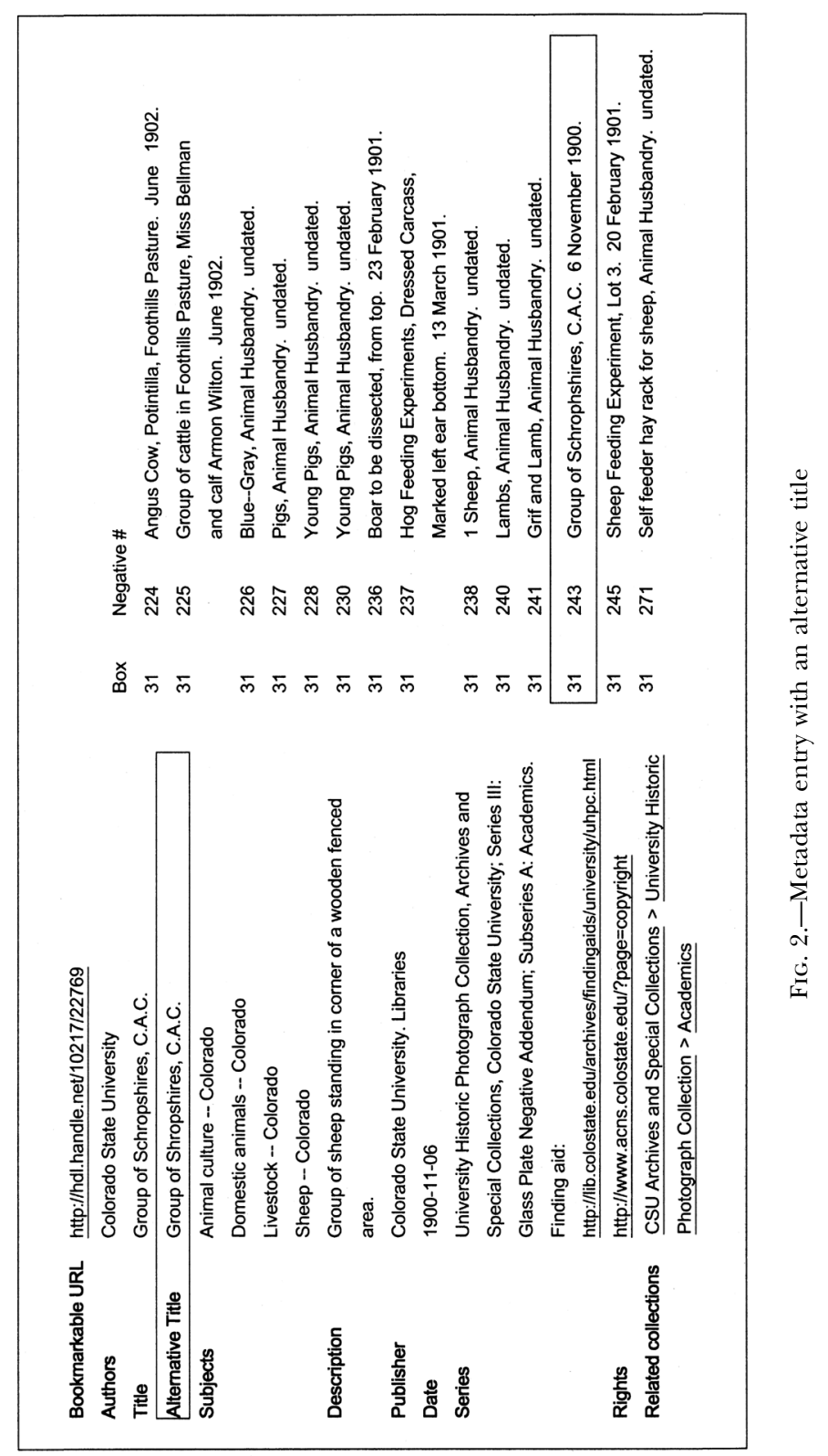


archivist's office was located in the same building, and she was available to answer any questions that arose. These included queries over proper handling, border cropping, and equipment problems, such as Newton's rings. ${ }^{6}$

The willingness of everyone involved to adapt and to remain flexible was also a major factor in the success of the UHPC digitization project. With thousands of digital images to create in nineteen months, the digital projects librarian soon discovered that image production was moving too slowly to finish before the scanning deadline. It was obvious that additional staff were needed, and funding was allocated to hire three student employees. The digital projects librarian adjusted the staff schedules, decreasing the amount of time they spent on other job responsibilities and increasing the amount of time they spent creating digital images. The Coordinator of Archives and Special Collections and the Annex archivists agreed to extend the hours at the Annex, increasing the rate of production, bringing the project to completion by the deadline.

The scope of this project revealed how collaboration occurred organically and became the project's organizational model. A project of this scope requires the expertise and cooperation of many unrelated groups and individuals, and sometimes bringing all the parties together can be a difficult undertaking. This experience proved that an open, flexible, collaborative approach to creating digital collections, coupled with good planning and effective methods of communication, is the optimal structure.

\section{Metadata Librarian}

The metadata librarian has several years of experience working with and creating metadata and catalog records. Previous digitization projects were focused and relatively small, however, compared to the 13,000 diverse images in the UHPC digitization project. Although the finding aid for the UHPC did include an item-level inventory, early in the project it became clear that the metadata for each image could not be custom built, nor could the metadata librarian create all the metadata herself. Instead, she focused on working with the project archivist to develop a plan for the creation of the metadata that would build on existing tools (most notably the finding aid and the spreadsheet used to manage the digitization of the images), training copy-cataloging staff in metadata, and being a resource for staff when they encountered problems.

6. Newton's rings are "a set of concentric circular fringes seen around the point of contact when a convex lens is placed on a plane surface (or on another lens), which join points where the intervening thin layer of air has the same thickness and are caused by interference between light reflected from the upper and lower surfaces" [23]. 
This close collaboration with the project archivist helped her understand and use several archival principles that expedited the project:

- Describing materials in the aggregate. Library of Congress Subject Headings were assigned at the subseries division level. For example, Series I: Glass Plate Negatives; Subseries B: Athletics was further divided by the sport depicted. The metadata librarian assigned the subjects: Baseball; Colorado Agricultural College-Baseball; and Colorado Agricultural College-Sports to all the images in the Baseball division under Athletics. This built on the organizational work of the project archivist.

- Preserving the organization of the creator. The images in the collection were numbered by the photographers, and there were several duplicate numbers. The image numbers were used as part of the digital master file name to facilitate matching metadata, image, and the finding aid, but the file names needed to be unique. To accomplish this, the librarians and the project archivist developed a system of appending a lower case "a," "b," etc. to the file name. Without understanding the importance of preserving the original numbering, the metadata librarian might have significantly changed the duplicate numbers, rather than modifying them just enough to make the file names unique.

- Organizing the collection to provide context. The digital asset management system used at CSUL offers the ability to create logical collections. These are predefined searches of the system that display as a collection. This is more flexible than placing each image in an itemized collection and allows a single digital object to be grouped in more than one logical collection. The project archivist was very interested in making sure that the images could be displayed together at the subseries level. Understanding this, the metadata librarian created identifiers for each image to support logical collections that used the finding aid grouping. The identifier consists of three parts: the first part is the collection code assigned to the collection by Archives and Special Collections (UHPC). The second part of the identifier is four characters standing for the series and subseries. The third part is a six-digit accession number, sequentially assigned. An identifier would then look like this: UHPCS01A201470. Using \% as a wild card character, a logical collection that looked for the string: UHPCS01A\% or UHPCS02A\% or UHPCS03A\% or UHPCS05A\% was built. This pulls together all the images in the subseries Academics, regardless of format. As stated earlier, series level arrangement is by format, followed by a topical subseries. Additional logical collections were created for each subseries. If, in the future, Archives and Special Collections would prefer to group the UHPC images by format, this option is still open, by creating logical collections that look for UHPCS01\% (glass plate 
negatives), UHPCS02\% (glass plate negative surrogates), etc. Constructing the identifiers as described above highlights the need for the metadata librarian to understand the archival organization of the collection in order to present the digital collection as intended by the project archivist.

The similarities between archival control and bibliographic control were fewer than originally thought. Creating the metadata for this project became an opportunity to combine the principles of archival description and detailed bibliographic control.

Conclusion

In spite of delays, in the nine months it took to digitize the first subcollections of glass plate negatives and magic lantern slides, project staff had created thousands of digital images, overcoming equipment problems, communication issues, and staff shortages. During the next ten months staff focused on completing the silver gelatin print subcollection, applying the lessons they learned to streamline the process. The success of this project is due to several factors: the institutional support given to the project, the effective avenues of communication established between the project participants, the use of project-tracking documentation, and the ability to remain flexible when faced with the challenges of differing professional philosophies.

Many of the problems encountered could not have been anticipated; they were revealed only during the creation of the digital collection. For example, when working with a large number of staff, it is advisable to identify department liaisons. This smaller group of liaisons (for CSUL, the Working Group) met to resolve problems while the project continued. The librarians and the project archivist remained flexible to change and brought their individual expertise to each issue to discover a solution, relying on open communication and each other's knowledge, skills, and experience.

Over forty people played a role in creating the UHPC Digital Collection. A celebration at a milestone of the project offered a vision of collaboration by simply glancing around the room and seeing administrators, faculty, staff, student employees, and volunteers mingling over desserts. Some institutions may suspect that collaboration on a large digital project may become unwieldy and unmanageable. The differing professional cultures that exist at CSUL are not a barrier to collaboration. On the contrary, digitization projects have the support of the CSUL administration and all project partners. To return to Peter Brantley's idea of bridging communities, this digital collaboration resulted in building and reinforcing bridges 
between internal and external communities. The celebration party was an illustration of the philosophy of bringing different communities together.

The project archivist, the digital projects librarian, and the metadata librarian now possess an appreciation of, and respect for, one another's professional vocabularies and professional philosophical foundations. By combining areas of specialization and expertise, they have made a large collection of university photographs available online, providing viewers a glimpse of the history of Colorado's land-grant university.

The results of collaboration extend beyond the few examples given here. Each professional tapped into the talents, skills, knowledge, experience, and professional cultures of her colleagues. The project archivist and the librarians documented their experiences for future digital projects, created closer professional relationships, and reached out to others to share what was learned. In doing so, they avoided having to learn or build every skill required to digitize a collection of this magnitude. Building the UHPC Digital Collection shows that convergence across traditional professional boundaries is not only possible, it is increasingly critical. The next challenges will be outreach, evaluating usability, and ensuring the preservation and accessibility of digital collections-efforts that will likely result in new forms of collaboration.

Appendix A

Metadata Elements

\begin{tabular}{l}
\hline Element \\
\hline Identifier \\
A unique identifier is required for all images in the Repository. \\
UHPC images are assigned an identifier that supports logical \\
collections. \\
Title is taken from the finding aid. Most images had a title written \\
on the enclosure or the reference card. When no title was sup- \\
plied by the creator, the project archivist created a title and brack- \\
Title \\
eted the supplied title. The titles were transcribed exactly as re- \\
corded in the finding aid. \\
The date that the digital image was created is extracted from the \\
digital image during the ingest process. This date is not viewable \\
in the end-user interface. \\
For all images in the UHPC, Colorado State University Libraries. \\
This element is a URL to the rights statement written and main- \\
tained by Colorado State University, which outlines permissible \\
uses of the images. \\
Library of Congress Subject Headings were assigned based on subser- \\
Rights \\
ies and further divisions in the finding aid. In some cases, an addi- \\
tional LCSH term is added for a specific species of plant or ani- \\
mal or when a person is named.
\end{tabular}


TABLE (Continued)

\begin{tabular}{|c|c|}
\hline Element & Description/Notes \\
\hline Type & $\begin{array}{l}\text { The nature or genre of the content of the digital resource. Two } \\
\text { Types have been identified for use in the UHPC: Still Image and } \\
\text { Text, and are taken from the DCMI Type Vocabulary. All images } \\
\text { are assigned Still Image; images with significant text that contrib- } \\
\text { utes to the intellectual content of the image are also assigned } \\
\text { Text. }\end{array}$ \\
\hline Format & $\begin{array}{l}\text { The Internet Media Type (MIME Type) of the digital resource itself. } \\
\text { This is extracted from the image during ingest and is not visible } \\
\text { to the end user, except as an icon that is the link to the image } \\
\text { and its full metadata. }\end{array}$ \\
\hline Format.Extent & $\begin{array}{l}\text { The file size of the JP2 access image. This is extracted from the im- } \\
\text { age during ingest. }\end{array}$ \\
\hline Metadata schema & $\begin{array}{l}\text { The name of the data dictionary to which the metadata conforms. } \\
\text { This will serve as a reference for migration and would account for } \\
\text { differences in metadata over time, as different versions of the data } \\
\text { dictionary may be created. }\end{array}$ \\
\hline Date.Original & $\begin{array}{l}\text { The date (when known) the original image was created. The date is } \\
\text { taken from the finding aid. When the date the original image was } \\
\text { created is unknown, the term "undated" is entered in this field. }\end{array}$ \\
\hline Source & $\begin{array}{l}\text { A description of the physical format of the original. Included is: the } \\
\text { format of the original (such as glass plate negative), whether the } \\
\text { image is colored or black and white, the dimensions of the origi- } \\
\text { nal, and any description of the condition of the original that was } \\
\text { noted by the project archivist. }\end{array}$ \\
\hline Relation.IsFormatOf & $\begin{array}{l}\text { A citation for the original image. All images in the UHPC are num- } \\
\text { bered. The negative/print number is recorded, followed by the ti- } \\
\text { tle, then the date (or undated), all taken from the finding aid. }\end{array}$ \\
\hline Relation.IsPartOf & $\begin{array}{l}\text { A citation for the collection, including Series and Subseries. The } \\
\text { URL for the finding aid follows the citation. }\end{array}$ \\
\hline Description & $\begin{array}{l}\text { A brief description of the image. This description provides text that } \\
\text { can be searched via keyword to aid in finding the image. }\end{array}$ \\
\hline Creator & $\begin{array}{l}\text { For the historical photographs in the UHPC, the creator is generally } \\
\text { not known. Colorado State University is recorded as the Creator } \\
\text { for these images. }\end{array}$ \\
\hline Contributor & $\begin{array}{l}\text { A Contributor is someone who contributed to the intellectual or ar- } \\
\text { tistic content but whose role is secondary to the Creator. }\end{array}$ \\
\hline Coverage.Temporal & $\begin{array}{l}\text { The date of the event/subjects depicted in the image. In some cases, } \\
\text { the archivist allowed using a date range for images that are } \\
\text { undated. }\end{array}$ \\
\hline Coverage.Spatial & $\begin{array}{l}\text { The geographic area depicted in the image. The format of the geo- } \\
\text { graphic name follows either the Library of Congress Authority File } \\
\text { (LCAF) or the Library of Congress Subject Cataloging Manual if } \\
\text { no place name is established in the LCAF. }\end{array}$ \\
\hline
\end{tabular}


TABLE (Continued)

\begin{tabular}{ll}
\hline \hline Element & \multicolumn{1}{c}{ Description/Notes } \\
\hline Language & If an image contains text significant enough to warrant the Type of \\
& Text, the language of that text is recorded. There are two lan- \\
guage fields: one field contains the three-letter code for the lan- \\
guage as defined by ISO 639-2; the second field contains the \\
spelled-out form of the language in English. \\
Title.Alternative & $\begin{array}{l}\text { Some transcribed titles include original misspellings. To facilitate re- } \\
\text { source discovery, a Title.Alternative with the correct spelling is } \\
\text { added. }\end{array}$ \\
\hline
\end{tabular}

\section{REFERENCES}

1. The University Historic Photographic Collection. http://lib.colostate.edu/archives/uhpc/.

2. Hunter, Gregory S. Developing and Maintaining Practical Archives. New York: Neal-Schuman, 2003.

3. Chen, Lucia S. "From Picture Collection to Picture Collection Online." Collection Building 23 (2004): 139-46.

4. Liu, Yan Quan. "Best Practices, Standards, and Techniques for Digitizing Library Materials: A Snapshot of Library Digitization Practices in the USA." Online Information Review 28 (2004): 338-445.

5. Lopatin, Laurie. "Library Digitization Projects, Issues, and Guidelines: A Survey of the Literature." Library Hi Tech 24 (2006): 273-89.

6. Michel, Peter. "Digitizing Special Collections: To Boldly Go Where We've Been Before." Library Hi Tech 23 (2005): 379-95.

7. Sutton, Shan. "Digitizing California History: Issues of Selection and Description." 37 (Winter 2008): 28-33.

8. Schellenberg, T. R. The Management of Archives. Chicago: University of Chicago Press, 1965.

9. Kahn, Herman. "Librarians and Archivists: Some Aspects of Their Partnership." American Archivist 7 (1944): 243-51.

10. Clark, Robert L., Jr., ed. Archive-Library Relations. New York: Bowker, 1976.

11. Birdsall, William F. "Archivists, Librarians, and Issues during the Pioneering Era of the American Archival Movement." Journal of Library History 14 (Fall 1979): 458-79.

12. Bernbom, Gerry; Lippincott, Joan; and Eaton, Fynette. "Working Together: New Collaborations among Information Professionals." CAUSE/EFFECT journal 22 (1999). http:// net.educause.edu/ir/library/html/cem/cem99/cem9922.html.

13. McCrank, Lawrence J., ed. Archives and Library Administration: Divergent Traditions and Common Concerns. New York: Haworth, 1986.

14. Maher, William J. "Improving Archives-Library Relations: User-Centered Solutions to a Sibling Rivalry.” Journal of Academic Librarianship 15 (January 1990): 355-63.

15. Brantley, Peter. "Architectures for Collaboration: Roles and Expectations for Digital Libraries.” EDUCAUSE Review 43 (March/April 2008): 31-38.

16. Kaczmarek, Joanne. "The Complexities of Digital Resources: Collection Boundaries and Management Responsibilities.” Journal of Archival Organization 4 (2006): 215-27.

17. Holz, Diana. "Technologically Enhanced Archival Collections: Using the Buddy System." Journal of Archival Organization 4 (2006): 29-44. 
COLLABORATING TO BUILD A DIGITAL COLLECTION 103

18. Tanackoviæ, Sanjica Faletar, and Badurina, Boris. "Collaboration as a Wave of Future: Exploring Experiences from the Croatian Archives." Library Hi Tech 26 (2008): 557-74.

19. Sutton, Shan. "Navigating the Point of No Return: Organizational Implications of Digitization in Special Collections." Portal: Libraries and the Academy 4 (2004): 239-42.

20. Rettig, Patricia J.; Shu Liu; Hunter, Nancy; and Level, Allison V. "Developing a Metadata Best Practices Model: The Experience of the Colorado State University Libraries." Journal of Library Metadata 8 (2008): 315-39.

21. Coleman, Sterling, Jr. "The Archival and Library Viewpoints of a Collection in a Digital Environment: Is There Any Room for Compromise?" Journal of Archival Organization 2 (2004): 103-15.

22. Benemann, William E. "Reference Implications of Digital Technology in a Library Photograph Collection.” Reference Services Review 22 (1994): 45-50.

23. Oxford English Dictionary Online. http://dictionary.oed.com/. 